\title{
PENERAPAN BLUD KPHP: AKANKAH MENUJU PENGELOLAAN HUTAN YANG TRANSPARAN, AKUNTABEL DAN PARTISIPATIF?
}

\author{
Oleh: \\ Pandriadi, Angka Wijaya, Mas Amah \\ Fakultas Ekonomi Universitas IBA \\ Jalan Mayor Ruslan Palembang
}

\begin{abstract}
ABSTRACK
This resarch starts from the evidence that deforestation and degradation rate in Musi Rawas District remain increase, particularly in KPHP Lakitan areas. Based on former research, one of problem roots is governance. So that's why this research aims to know wether implementation of BLUD in KPHP Lakitan will make better governance in forest governance that may reduce the rate of deforestation and degradation. This research is qualitative research that tried to find data and information as much as possible by using deep interview and Focus Group Discussion (FGD). The informan in this research are government staffs, poeple who stay in or suround the forest area, and business companies. The result shows that implementing BLUD on KPHP Lakitan may give room for KPHP Lakitan to improve forest governance by using tranparancy, accountable, and participative concepts, therefore this is potentially to reduce the rate of deforestation and degradation in KPHP Lakitan's areas.
\end{abstract}

Keywords: BLUD, Transparent, Accountable, Participatory

\begin{abstract}
ABSTRAK
Penelitian ini berawal dari bukti bahwa laju deforestasi dan degradasi di Kabupaten Musi Rawas tetap meningkat, terutama di wilayah KPHP Lakitan. Berdasarkan penelitian terdahulu, salah satu akar masalah adalah pemerintahan. Oleh karena itu penelitian ini bertujuan untuk mengetahui implementasi BLUD di KPHP Lakitan akan membuat tata kelola yang lebih baik dalam tata kelola hutan yang dapat mengurangi laju deforestasi dan degradasi hutan. Penelitian ini merupakan penelitian kualitatif yang berusaha mencari data dan informasi sebanyak mungkin dengan menggunakan wawancara mendalam dan Focus Group Discussion (FGD). Informan dalam penelitian ini adalah pegawai pemerintah, masyarakat yang tinggal di atau di sekitar kawasan hutan, dan perusahaan bisnis. Hasilnya menunjukkan bahwa penerapan BLUD pada KPHP Lakitan dapat memberi ruang bagi KPHP Lakitan untuk memperbaiki tata kelola hutan dengan menggunakan konsep transparan, akuntabel, dan partisipatif, sehingga berpotensi mengurangi laju deforestasi dan degradasi di kawasan KPHP Lakitan.
\end{abstract}

Kata Kunci: BLUD, Transparan, Akuntabel, Partisipatif 


\section{PENDAHULUAN}

Pembentukan Peraturan Pemerintah (PP) No. 23 Tahun 2005 tentang Pengelolaan Keuangan Badan Layanan Umum (BLU) adalah amanat dari Pasal 69 ayat (7) UU No. 1 Tahun 2004 tentang Perbendaharaan Negara. PP tersebut bertujuan untuk meningkatkan pelayanan publik oleh Pemerintah._Sebelumnya tidak ada pengaturan yang spesifik mengenai unit pemerintahan yang melakukan pelayanan kepada masyarakat. Sebuah KPHP dapat menerpakan BLU karena KPHP mengelola sebuah kawasan yang bukan hanya bertujuan untuk pengelolaan hutan yang lestari tetapi juga dalam rangka mengembangkan perekonomian masyarakat setempat. Saat ini, selain KPHP Model Lakitan terdapat beberapa KPH lain yang juga merintis penerapan BLU yaitu KPH Gula Raya di Kendari dan KPH Yogyakarta.

Kabupaten Musi Rawas (Mura) termasuk salah satu kabupaten di Provinsi Sumatera Selatan yang memiliki kawasan hutan cukup luas, dimana dari 1,2 juta Ha luas kabupaten ini 48 persennya merupakan kawasan hutan. Namun demikian, Pemerintah Kabupaten Mura (selanjutnya disebut Pemkab Mura) masih menghadapi berbagai kendala dalam pengelolaan hutan, terutama deforestasi hutan yang terus terjadi.

Dari uraian di atas maka motivasi penelitian ini adalah: Pertama, untuk memberikan kontribusi yang nyata sebagai seorang akademisi dalam upaya perbaikan tata kelola hutan dan lahan melalui sebuah kajian penerapan PPK BLUD pada institusi kehutanan. Selama ini penerapan PPK BLUD lebih banyak dilakukan pada instansi di bidang kesehatan, pendidikan dan pelatihan, sehingga peneliti sangat termotivasi untuk mengetahui apakah institusi kehutanan (dalam hal ini KPHP) dapat juga menerapkan PPK BLUD sebagaimana institusi kesehatan, pendidikan, pelatihan yang telah terlebih dahulu menerapkannya. Kedua, untuk meyakinkan semua pihak yang berkepentingan bahwasannya penerapan PPK BLUD pada KPHP akan membuat pengelolaan hutan menjadi lebih transparan, akuntabel dan partisipatif sehingga dapat mengurangi tingkat deforestasi dan degradasi hutan.

Berkaitan dengan motivasi penelitian di atas maka peneliti merumuskan pertanyaan penelitian sebagai berikut: Pertama, Apakah sebuah KPHP dapat menerapkan PPK BLUD? dan kedua, apakah penerapan PPK BLUD dapat menjamin pengelolaan hutan yang lebih transparan, akuntabel dan partisipatif?. 
Sesuai rumusan pertanyaan di atas maka peneliti bertujuan agar penelitian ini dapat menjawab pertanyaan penelitian yang telah dirumuskan, meliputi apakah KPHP berpotensi untuk menerapkan PPK BLUD dan apakah setelah penerapannya nanti dapat menjamin pengelolaan hutan yang lebih transparan, akuntabel dan partisipatif, sehingga pada akhirnya dapat berkontribusi dalam pengurangan tingkat deforestasi dan degradasi hutan di kawasan KPHP Lakitan khususnya dan Kabupaten Musi Rawas pada umumnya.

\section{KAJIAN PUSTAKA}

KPH yang merupakan kesatuan pengelolan hutan terkecil sesuai fungsi pokok dan peruntukannya yang dapat dikelola secara efisien dan lestari, bertanggung jawab terhadap pelaksanaan tata hutan dan penyusunan rencana pengelolaan hutan serta penyelenggaraan pengelolaan hutan (PP No 6/2007).

Menurut Kartodihardjo et al. (2011) Kesatuan Pengelolaan Hutan berperan sebagai penyelenggara pengelolaan hutan di lapangan atau di tingkat tapak. Peran ini menjadi kebutuhan Pemerintah dan Pemerintah Daerah sebagai "penguasa" sumberdaya hutan berdasarkan mandat dari Undang-undang yang menguasai hutan negara. Dalam prakteknya KPH menyelenggarakan penguasaan sumberdaya hutan itu bukan dalam arti memberi izin pemanfaatan hutan melainkan melakukan pengelolaan sehari-hari. Dalam hal demikian itu, KPH menjadi pusat informasi mengenai kekayaan alam sekaligus menata kawasan hutan menjadi bagian-bagian yang dapat dimanfaatkan oleh berbagai izin maupun dimanfaatkan melalui kegiatan yang direncanakan dan dijalankan sendiri. Apabila kegiatan demikian itu dapat dilakukan dengan baik, maka KPH menjadi garis depan untuk mewujudkan harmonisasi pemanfaatan hutan oleh berbagai pihak.

Tekad untuk membangun KPH telah dimandatkan dalam UU Nomor 41 Tahun 1999 tentang Kehutanan dan lebih lanjut ditegaskan kembali dalam PP Nomor 44 Tahun 2004 tentang Perencanaan Kehutanan dan PP Nomor 6 Tahun 2007 tentang Tata Hutan dan Penyusunan Rencana Pengelolaan Hutan serta Pemanfaatan Hutan.

Badan Layanan Umum, yang selanjutnya disebut BLU, adalah instansi di lingkungan Pemerintah baik pusat maupun daerah yang dibentuk untuk memberikan pelayanan kepada masyarakat berupa penyediaan barang dan/atau jasa yang dijual tanpa mengutamakan mencari keuntungan dan dalam melakukan kegiatannya didasarkan pada 
prinsip efisiensi dan produktivitas (UU No 1/2004). Sementara itu Pola Pengelolaan Keuangan Badan Layanan Umum, yang selanjutnya disebut PPK-BLU, adalah pola pengelolaan keuangan yang memberikan fleksibilitas berupa keleluasaan untuk menerapkan praktek-praktek bisnis yang sehat untuk meningkatkan pelayanan kepada masyarakat dalam rangka memajukan kesejahteraan umum dan mencerdaskan kehidupan bangsa (PP No 23/2005).

Berdasarkan Undang-Undang Nomor 1 Tahun 2004 Tentang Perbendaharaan Negara, BLU bertujuan untuk meningkatkan pelayanan kepada masyarakat dalam rangka memajukan kesejahteraan umum dan mencerdaskan kehidupan bangsa dengan memberikan fleksibilitas dalam pengelolaan keuangan berdasarkan prinsip ekonomi dan produktivitas, dan penerapan praktek bisnis yang sehat.

Dalam manajemen organisasi publik dikenal istilah New Public Management (NPM) yang merujuk kepada perubahan organisasi dan manajemen birokrasi pemerintahan. Model ini dianggap sebagai perpaduan antara dua kerangka ide; generic managerialism dan perkembangan baru dalam teori ekonomi. Pada prinsipnya, NPM ingin mengadaptasikan prinsip-prinsip pengelolaan lembaga privat ke dalam lembaga-lembaga publik. Pada perkembangannya, seiring perkembangan demokrasi dan meningkatnya kontrol masyarakat, maka model NPM digantikan dengan paradigma yang lebih luas mengenai tata kelola publik (public governance). Prinsip-prinsip umum NPM tetap digunakan, namun New Public Governance (NPG) menambahkan aspek yang sangat krusial, yakni proses dan partisipasi (Zamjani, 2011:4). Dalam kaitannya dengan upaya menjadikan KPHP menjadi sebuah BLU maka pola NPG akan dapat diterapkan karena mengedepankan adanya proses dan partisipasi seluruh elemen yang ada, baik pemerintah, swasta maupun masyarakat.

Namun demikian, pembangunan KPH bukan tanpa masalah, penelitian yang dilakukan oleh Kartodihardjo et.al (2011) mengidentifikasi beberapa masalah dalam pembangunan $\mathrm{KPH}$, yaitu:

1. Tidak seluruh pemerintah daerah memberikan dukungan dalam pembangunan $\mathrm{KPH}$ terutama dalam pembentukan organisasi KPH. Alasan utama adalah perlunya anggaran untuk menghidupkan organisasi KPH tersebut.

2. Masih terbatasnya pengertian dan pemahaman terhadap fungsi dan manfaat KPH bagi pembangunan kehutanan. Hal demikian ditunjang oleh kenyataan bahwa penetapan kewenangan pemerintahan maupun pembentukan organisasi daerah 
tidak mempertimbangkan pentingnya pengelolaan wilayah atau organisasi berbasis territorial. Kerangka kerja pemerintah hanya didasarkan oleh pemanfaatan komoditas dari sumber daya alam yang ada di kawasan hutan.

3. Terbatasnya sumber daya manusia yang memahami dan mempunyai kapabilitas untuk menjalankan organisasi KPH.

Permasalahan yang sama juga muncul berdasarkan hasil penelitian yang dilakukan oleh Puspariani (2011) yang melakukan penelitian tentang implementasi kebijakan pembangunan Kesatuan Pengelolaan Hutan Produksi (KPHP) Model Lalan Kabupaten Musi Banyu Asin Sumatera Selatan. Hasil investigasi menunjukkan bahwa lemahnya pemahaman atas organisasi $\mathrm{KPH}$, keterbatasan SDM, dan lambatnya implementasi kebijakan pengembangan KPHP ini disinyalir telah ikut menyumbang deforestasi hutan di Kabupaten Musi Banyuasin.

Untuk menyelesaikan persoalan-persoalan yang dihadapi oleh KPH sebagaimana yang diuraikan di atas ada beberapa alternatif yang bisa dilakukan. Menurut Kartodihardjo (2011) salah satu alternatif untuk menyelesaikan berbagai persoalan yang membelit KPHP adalah dengan menetapkan arah tanggung jawab KPH termasuk arah perubahan pengelolaan keuangan KPH menjadi pola pengelolaan BLU karena langkah ini dianggap relevan untuk mencapai tujuan jangka pendek dan jangka panjang yang telah ditetapkan oleh KPH.

Kajian yang dilakukan oleh Nugroho (2013) adalah tentang suatu sistem pengelolaan keuangan yang bisa diimplementasikan dalam organisasi KPH, sehingga bisa melakukan bisnis tetapi tetap bisa memenuhi fungsinya sebagai penyedia jasa layanan publik dalam pengelolaan hutan secara lestari. Dalam kajian ini diungkapkan bahwa di antara banyak hambatan dalam pembangunan KPH terdapat satu hambatan yang perlu segera diatasi yaitu belum jelasnya kebijakan dan aturan tentang pendanaan baik pada tahap pembangunan maupun operasionalisasi KPH, termasuk pengelolaan pendapatan operasional KPH. Hambatan ini akan mempengaruhi kinerja KPH sebagai unit yang mandiri (self-financing management units) dan profesional dalam mencapai tujuan pengelolaan hutan yang lestari. Untuk mengatasi hambatan tersebut diperlukan kepastian dan keamanan dalam melakukan kegiatan investasi dan pengelolaan pendapatan secara mandiri yang dapat diberlakukan secara nasional. 
Hasil kajiannya menghasilkan rekomendasi bahwa untuk menjamin fleksibilitas pengelolaan KPH adalah bentuk organisasi yang mampu menyelenggarakan fungsi-fungsi publik dan sekaligus fungsi privat atau bisnis, yang diistilahkan dengan organisasi semi pemerintah (quasi public). Bentuk organisasi quasi public yang paling optimal adalah Pola Pengelolaan Keuangan Badan Layanan Umum Daerah (PPK-BLUD). Beberapa pokok pikiran dalam pengembangan KPHP dengan PPK-BLUD. Pertama, KPHP dibentuk untuk memastikan pengelolaan hutan dapat berjalan secara optimal, efisien, dan lestari. Kedua, Pengelolaan hutan harus mendatangkan kesejahteraan bagi masyarakat. Ketiga, menjalankan pelayanan publik yang sekaligus berorientasi pada efisiensi dan produktivitas sebagaimana ciri entitas bisnis. Keempat, implikasi dari butir ketiga tersebut maka organisasi KPHP yang menerapkan PPK-BLUD akan bersifat semi pemerintah (quasi public governance). Efisiensi dan produktivitas mengandung arti bahwa KPH dapat mengurangi rantai birokrasi, dapat menekan biaya transaksi (high cost economy), menyediakan pelayanan yang murah dan cepat (responsif) serta mampu meningkatkan kualitas dan kuantitas pelayanan umum bidang kehutanan. Kelima, agar organisasi tersebut dapat berjalan optimal diperlukan fleksibilitas berupa keleluasaan untuk menerapkan praktek-praktek bisnis yang sehat.

Studi mengenai pengaruh implementasi sebuah KPHP sebelum dan sesudah menjadi BLU saat ini belum ditemukan, oleh karena itu penelitian ini berupaya membandingkan dengan institusi lain yang pernah mengimplementasikan BLU, terutama di bidang kesehatan. Meidyawati (2011) dalam penelitiannya yang berjudul "Analisis Implementasi Pola Pengelolaan Keuangan Badan Layanan Umum (PPK-BLU) Pada Rumah Sakit Stroke Nasional Bukit Tinggi” menghasilkan beberapa kesimpulan, antara lain adalah: Pertama, rumah sakit ini telah mengimplementasikan semua persyaratan administratif BLU yang meliputi Pola Tata Kelola, Rencana Strategis Bisnis, Rencana Bisnis Anggaran, Standar Pelayanan Minimal dan Laporan Keuangan. Kedua, implementasi PPK-BLU telah memberikan peningkatan nilai kinerja, peningkatan pertumbuhan pendapatan, peningkatan kemandirian rumah sakit, serta memberikan manfaat langsung dalam peningkatan layanan kepada masyarakat. Membandingkan antara potensi penerapan BLUD pada KPHP dengan penerapan BLUD pada bidang kesehatan seperti rumah sakit dapat dikatakan comparable karena yang dibandingkan adalah dampak dari 
penerapan BLUD tersebut, bukan pada jenis layanan antara kedua institusi tersebut. Hal ini ditambah karena saat ini belum ada KPHP lain yang menerapkan BLUD sehingga peneliti mengambil perbandingan dengan rumah sakit.

Penelitian lain yang juga masih relevan adalah penelitian yang dilakukan oleh Pandriadi (2011) yang mengkaji dan menganalisis kelayakan Balai Latihan Kerja (BLK) Dinas Tenaga Kerja dan Transmigrasi Kabupaten Musi Rawas untuk dikelola dengan konsep BLU. Meskipun penelitian ini dilakukan untuk BLK, namun mengingat penelitian ini dilakukan di lokasi yang sama (Kabupaten Musi Rawas) maka output penelitian ini bisa dijadikan rujukan bagi penelitian BLU KPHP Model Lakitan yang akan dilaksanakan. Berdasarkan hasil temuan dalam penelitian ini, terdapat beberapa hal yang harus ditingkatkan dalam rangka peningkatan kapasitas BLK menjadi BLU yaitu peningkatan pada sumber daya manusia dan pola tata kelola. Mengingat BLK ini dan KPHP Model Lakitan berada di daerah yang sama bukan tidak mungkin permasalahan yang dihadapi oleh BLK ini akan sama dengan permasalahan yang dihadapi oleh KPHP Model Lakitan yang akan menjadi obyek dalam penelitian ini.

\section{METODA PENELITIAN}

Ruang lingkup kegiatan penelitian ini meliputi beberapa kegiatan pokok, yaitu: pertama, melakukan kajian potensi penerapan PPK BLUD pada KPHP Lakitan Kabupaten Musi Rawas, meliputi kelayakan teknis, ekonomis dan potensi usaha serta inventarisasi asset yang dimiliki. Kedua, melakukan analisis potensi dampak penerapannya pada perbaikan tata kelola hutan yang lebih transparan, akuntabel dan partisipatif.

Berdasarkan kedua ruang lingkup penelitian tersebut di atas peneliti ini menggunakan pendekatan kualitatif dalam melaksanakan rangkaian proses penelitian. Alasan penggunaan metode ini karena obyek yang dijadikan dalam penelitian ini adalah KPHP Model Lakitan dengan semua kondisi dan permasalahan yang ada, dimana kondisi dan permasalahan tersebut belum tergambar cukup jelas, sehingga dengan metode kualitatif memungkinkan peneliti sebagai instrumen kunci penelitian mengidentifikasi dan mengeksplorasi kondisi yang ada di KPHP Model Lakitan, baik melalui studi literatur maupun wawancara dengan narasumber kunci. 
Data yang digunakan dalam penelitian ini terdiri dari data sekunder dan data primer. Data sekunder diperoleh melalui desk study dengan melakukan penelusuran data yang relevan dengan penelitian ini, baik berupa laporan-laporan dari dinas/instansi terkait (misalnya Kementrian Kehutanan, Dinas Kehutanan Mura, Bappeda Mura, BPS Mura dan KPHP Model Lakitan), lembaga penelitian, perguruan tinggi dan lain-lain. Sementara itu data primer dikumpulkan oleh peneliti melalui serangkaian kegiatan wawancara lapangan dan melakukan Focus Group Discussion (FGD). Teknis analisis yang digunakan adalah dengan menggunkan teknik analisis deskriptif kualitatif denga menjelaskan berbagai fakta dan hasil temuan baik yang berasal dari data primer maupun sekunder.

\section{HASIL PENELITIAN DAN DISKUSI}

Untuk menjadi sebuah BLU, maka sebuah institusi harus memenuhi persyaratan sebagaimana diatur menurut Pasal 4 PP No. 23 Tahun 2005, meliputi persyaratan substantive, teknis dan administratif.

Memperhatikan persyaratan di atas, secara prinsip KPHP Model Lakitan telah memenuhi persyaratan subtantif dan persyaratan teknis. Oleh karena itu, maka yang masih harus dipersiapkan oleh KPHP Model Lakitan sebelum mengajukan permohonan menjadi BLUD adalah persyaratan administratif. Di antara persyaratan administratif yang harus disiapkan adalah dokumen Rencana Strategi Bisnis (Renstra Bisnis), Pola tata Kelola dan Standar Pelayanan Minimal.

\section{Tabel 1}

Kondisi KPHP Model Lakitan dalam Perspektif Persyaratan Substantif, Teknis dan Administratif

\begin{tabular}{|c|c|c|}
\hline $\begin{array}{c}\text { Jenis } \\
\text { Persyaratan }\end{array}$ & Hal Yang Harus dipenuhi & $\begin{array}{c}\text { Pemenuhan } \\
\text { Oleh KPHP } \\
\text { Model Lakitan }\end{array}$ \\
\hline \multirow{3}{*}{ Substantif } & Penyediaan barang dan/atau jasa layanan umum; & Memenuhi \\
\hline & $\begin{array}{l}\text { Pengelolaan wilayah/kawasan tertentu untuk tujuan } \\
\text { meningkatkan perekonomian masyarakat atau layanan } \\
\text { umum; dan/atau }\end{array}$ & Memenuhi \\
\hline & $\begin{array}{l}\text { Pengelolaan dana khusus dalam rangka meningkatkan } \\
\text { ekonomi dan/atau pelayanan kepada masyarakat. }\end{array}$ & Tidak memenuhi \\
\hline
\end{tabular}




\begin{tabular}{|c|c|c|}
\hline \multirow{4}{*}{ Teknis } & $\begin{array}{l}\text { Kinerja pelayanan di bidang tugas pokok dan fungsinya } \\
\text { layak dikelola dan ditingkatkan pencapaiannya melalui } \\
\text { BLU sebagaimana direkomendasikan oleh } \\
\text { menteri/pimpinan lembaga/kepala SKPD sesuai dengan } \\
\text { kewenangannya; }\end{array}$ & Memenuhi \\
\hline & $\begin{array}{l}\text { Kinerja keuangan satuan kerja instansi yang } \\
\text { bersangkutan adalah sehat sebagaimana ditunjukkan } \\
\text { dalam dokumen usulan penetapan BLU. }\end{array}$ & Memenuhi \\
\hline & $\begin{array}{l}\text { Pernyataan kesanggupan untuk meningkatkan kinerja } \\
\text { pelayanan, keuangan, dan manfaat bagi masyarakat; }\end{array}$ & Dapat disiapkan \\
\hline & Pola Tata Kelola & Sudah ada \\
\hline \multirow{4}{*}{ Administratif } & Rencana Strategi Bisnis & Sudah ada \\
\hline & Laporan Keuangan Pokok & Sudah ada \\
\hline & Standar Pelayanan Minimum & Sudah ada \\
\hline & $\begin{array}{l}\text { Laporan Audit Terakhir atau pernyataan bersedia } \\
\text { untuk diaudit secara independen }\end{array}$ & $\begin{array}{l}\text { Dapat disiapkan } \\
\text { oleh KPHP }\end{array}$ \\
\hline
\end{tabular}

Sumber : Data diolah, 2015.

Dari tabel di atas dapat diperoleh gambaran bahwasannya KPHP Model Lakitan pada dasarnya dapat memenuhi ketiga persyaratan dalam pengajuan BLUD. Untuk persyaratan substantif, hanya perlu memenuhi salah satu dari kriteria saja, sehingga meskipun KPHP Model Lakitan tidak mengelola dana khusus bagi pengembangan ekonomi masyarakat, namun sudah memenuhi aspek substantif yang lain, yaitu memberi pelayanan kepada masyarakat dan melakukan pengelolaan sebuah kawasan.

Pertanyaan apakah sebuah KPHP akan menjadi institusi yang lebih transparan, akuntabel dan partisipatif setelah menjadi BLUD sebetulnya akan sama maknanya dengan pertanyaan apakah konsep BLUD dapat menjamin sebuah institusi untuk beroperasi di bawah koridor transparan, akuntabel dan partisipatif. Pertanyaan ini kemudian akan bermuara pada pertanyaan apakah KPHP yang dikelola secara PPK BLUD akan berdampak pada perbaikan tata kelola hutan dan lahan dalam rangka mengurangi laju deforestasi dan degradasi hutan di wilayah KPHP tersebut.

Jika kita ingin menjawab pertanyaan tersebut secara cepat maka jawabannya tentu saja pengelolaan KPHP dengan PPK BLUD tidak akan memberi pengaruh langsung pada pengurangan laju deforestasi dan degradasi hutan, atau dengan kata lain BLUD KPHP 
tidak serta merta menawarkan sebuah solusi akhir dari permasalahan kehutanan. Namun demikian, PPK BLUD dapat dianggap sebagai variabel antara yang menghubungkan dua sisi dalam tataran pengelolaan hutan, yaitu pengelola hutan dan hutan itu sendiri.

Hal ini dapat dimengerti manakala kita menganalogikan kasus kehutanan (deforestasi dan degradasi hutan) dengan analogi yang cukup sederhana yaitu bagaimana seorang pengangguran akan bisa mendapatkan pekerjaan yang layak dengan kondisi persaingan yang cukup tinggi dan tingkat kesempatan kerja yang rendah. Artinya dari sisi penganggur tersebut memiliki banyak kendala, begitu pula dari sisi lapangan kerja juga memiliki banyak kendala berupa persyaratan dan lain sebagainya. Pertanyaannya adalah apakah kesempatan kerja yang harus menyesuaikan dengan kondisi penganggur, ataukah penganggur tersebut yang akan menyelesaikan permasalahannya sendiri dan kemudian mencari cara mendapatkan pekerjaan yang diinginkan. Dengan demikian, sangat sulit jika penyelesaian permasalahan kehutanan hanya diselesaikan dengan cara menunggu bahwa masalah itu akan selesai sendiri. Satu contoh kasus di Kabupaten Ogan Komering Ilir (OKI) Provinsi Sumatera Selatan dimana data menunjukkan bahwa tingkat ilegal logging di daerah tersebut menurun tajam. Membaca data ini tentu kita tidak terburu-buru untuk bersuka cita karena menganggap kesadaran masyarakat untuk tidak merampas hutan telah meningkat karena yang sebenarnya terjadi penurunan tersebut lebih disebabkan karena tidak ada lagi kawasan hutan yang bisa dirampas.

Oleh karena itu dengan penguatan kapasitas KPHP melalui penerapan PPK BLUD akan memberi kekuatan baru bagi KPHP untuk menyelesaikan permasalahanpermasalahan yang dihadapinya. Saat mereka telah berhasil menyelesaikan permasalahanpermasalahan tersebut saat itulah membuktikan bahwa BLUD memberikan andil yang tidak langsung pada perbaikan tata kelola hutan dan lahan.

Jaminan awal bahwa BLUD akan memberi jaminan perbaikan tata kelola organisasi sebetulnya tercermin dalam persyaratan pembentukan sebuah BLUD, dimana salah satu persyaratan administratif yang diperlukan adalah pola tata kelola yang baik dengan memperhatikan prinsip-prinsip transparansi, akuntabilitas, responsibilitas dan independensi (pasal 31 Permendagri No 61/2007).

KPHP Model Lakitan Kabupaten Musi Rawas merupakan satuan kerja perangkat daerah yang berada dibawah Satuan kerja perangkat daerah Dinas Kehutanan Kabupaten 
Musi Rawas. Seluruh proses pengelolaan organisasi berada dibawah kendali organisasi induknya. Proses tatakelola organisasi dapat meliputi proses perencanaan, penganggaran, penatausahaan, pelaksanaan dan pertanggungajawaban. Rangkaian proses tersebut berada di bawah kendali Satuan kerja perangkat daerah Dinas Kehutanan Kabupaten Musi Rawas. Proses perencanaan mulai dari musrenbang desa atau kelurahan, kabupaten, forum SKPD, dan provinsi serta nasional berada dibawah satuan kerja induknya. Proses penganggarannya juga masih menginduk pada satuan kerja induknya, demikian juga pelaksanaaan program dan kegiatan serta pertanggungjawaban. Laporan keuangan yang disusun masih atas nama Dinas Kehutanan.

Secara umum transparansi dan akuntabilitas KPHP Model Lakitan tercermin dalam dokumen pola tata kelola yang dengan gambaran sebagai berikut:

\section{$\underline{\text { Akuntabilitas }}$}

Mendasari segala potensi yang ada dan memperhatikan visi pembangunan kehutanan provinsi dan kabupaten, KPHP Model Lakitan mempunyai visi: "KPHP Model Lakitan sebagai pemasok bahan baku industri kayu dan non kayu secara berkelanjutan menuju KPH mandiri”. Untuk mencapai visi tersebut KPHP Model Lakitan menjalankan misi sebagai berikut: (1) memantapkan pengukuhan dan penataan kawasan secara legal formal serta penataan hak-hak masyarakat sebagai landasan pengelolaan kawasan, (2) menjalin kerjasama, kolaborasi dan kemitraan dengan berbagai pihak dalam kerangka percepatan optimalisasi pengelolaan kawasan hutan, (3) meningkatkan pemberdayaan masyarakat melalui partisipasi masyarakat setempat dalam mengakses sumberdaya hutan dalam berbagai skema pengelolaan, (4) membangun kelembagaan yang kokoh dan kuat serta meningkatkan manajemen pengelolaan hutan.

Akuntabilitas di lingkungan KPHP-BLUD pada dasarnya merupakan pertanggungjawaban pengelolaan sumberdaya serta pelaksanaan kebijakan yang dipercayakan kepada KPHP dalam mencapai tujuan yang telah ditetapkan secara periodik sesuai dengan visi dan misi KPHP yang telah diuraikan di atas. Akuntabilitas yang dimaksud meliputi akuntabilitas program, akuntabilitas kegiatan dan akuntabilitas keuangan.

\section{Akuntabilitas Program}


Sebagai perwujudan akuntabilitas program, Kepala KPHP Model Lakitan menyusun Rencana Pengelolaan Hutan Jangka Panjang (RPHJP) KPHP Model Lakitan 2014- 2023 dengan mengacu kepada Peraturan Dirjen Planologi No. P.5/VII-WP3H/2012, Peraturan Menteri Kehutanan No. 46/Menhut-II/2013, RPJMD Kabupaten Musi Rawas, dan Rencana Strategis Dinas Kehutanan Tahun 2010-2015. Program disusun berdasarkan aspirasi dari masing-masing unit/bidang dan disesuaikan dengan strategi pengembangan KPHP. Program yang telah disusun kemudian ditetapkan batas waktu pencapaian program dan harus diacu serta dijabarkan lebih lanjut menjadi kegiatan yang akan dilaksanakan oleh setiap unit kerja. Untuk mengukur tingkat keberhasilan program, diperlukan parameter/indicator kinerja setiap program.

Pertanggungjawaban program berupa laporan triwulanan dan operasional dilakukan oleh penanggungjawab program dan kegiatan. Laporan tersebut selanjutnya menjadi bahan evaluasi kinerja KPHP dan dikompilasi menjadi Laporan Akuntabilitas Kinerja Instansi Pemerintah (LAKIP) yang merupakan pertanggungjawaban pimpinan KPHP kepada Bupati selaku Kepala Daerah. Evaluasi triwulanan wajib dilakukan untuk melihat kesesuaian kegiatan dengan perencanaan dan juga melihat potensi kegagalan atau keberhasilan program.

Mekanisme manajemen dalam melaksanakan akuntabilitas program adalah sebagai berikut

\section{Perencanaan (planning)}

Di bidang kelola produksi, kelola ekologi, dan kelola social-ekonomi perencanaan program dilakukan melalui tahapan survey lapangan dan analisis potensi pemanfaatan hasil hutan kayu dan non kayu serta kondisi social budaya di sekitar kawasan pengelolaan yang dibahas dan ditetapkan melalui rapat kerja KPHP yang selanjutnya akan disampaikan kepada unit-unit organisasi KPHP untuk dijabarkan dan dilaksanakan.

Sementara untuk perencanaan di bidang pengembangan kelembagaan dan kerjasama, KPHP menetapkan bahwa setiap usulan program yang berasal dari masing-masing unit organisasi disampaikan kepada Kepala KPHP yang selanjutnya akan dibahas bersama-sama dengan pejabat teknis dan pejabat keungan selaku pejabat pengelola KPHP-BLUD.

\section{Pelaksanaan (actuating)}


Pelaksanaan program dilakukan dengan menunjuk penanggungjawab program (sesuai dengan RPHJP KPHP) untuk menjalankan sesuai dengan apa yang ditetapkan dalam rapat kerja dan melaporkannya kepada Kepala KPHP.

\section{Pengukuran (measurement)}

Pencapaian program diukur berdasarkan presentasi realisasi capaian program oleh masing-masing unit serta peningkatan kinerja layanan.

\section{Pelaporan (reporting)}

Pelaporan program dilakukan oleh penanggungjawab program secara periodic, yaitu secara bulanan, triwulanan, semesteran dan tahunan. Pelaporan program dan unit-unit pelaksana ditujukan ke Kepala KPHP untuk dikompilasikan dan dilaporkan menjadi Laporan Akuntabilitas Kinerja Instansi (LAKIP) dan dilaporkan ke Bupati selaku Kepala Daerah serta Dewan Pengawas. Tiap akhir tahun setelah menjadi BLUD KPHP Model Lakitan juga akan menyusun Laporan Kinerja sesuai dengan PP No.8 Tahun 2006 tentang Pelaporan Keuangan dan Kinerja Instansi Pemerintahan.

\section{Pemantauan (controlling)}

Pemantauan dilakukan secara teratur dan berkesinambungan yang dilaksanakan secara bulanan, triwulanan, semesteran dan tahunan dan penanggung jawab program masing-masing unit kepada Pejabat Teknis untuk program yang bersifat teknis dan Pejabat Keuangan untuk program yang berkaitan dengan kelembagaan dan keuangan. Hasil pemantauan ini secara triwulanan akan dilaporkan kepada Kepala Daerah serta Dewan Pengawas. Selain itu controlling juga dimandatkan kepada KPH untuk mengontrol pelaksanaan pengelolaan hutan oleh pemegang izin.

\section{Akuntabilitas Kegiatan}

Akuntabilitas kegiatan mencakup mekanisme/prosedur pencapaian tujuan yang di dalamnya mengandung kebijakan-kebijakan mulai dari perencanaan sampai dengan pertanggungjawaban. Akuntabilitas kegiatan juga dibangun dengan penetapan Standar Pelayanan Minimum serta target kerja dari setiap kegiatan. Untuk mengukur dan menjamin keterlaksanaan dam mempertanggungjawabkan kegiatan-kegiatan ini KPHP Model Lakitan akan menetapkan Standard Operating Procedure (SOP). Pembuatan SOP tersebut melibatkan banyak pihak yang terkait dengan kegiatan pada semua tingkatan. Untuk membuat SOP ini KPHP Model Lakitan berupaya untuk mendapatkan dukungan pendanaan baik dari dalam maupun dari luar dengan skema kerjasama.

Dalam melaksanakan akuntabilitas kegiatan, mekanisme manajemen yang diterapkan dalam KPHP adalah sebagai berikut :

\section{Perencanaan (planning)}


Perencanaan kegiatan di bidang kelola produksi, kelola ekologi, kelola social-ekonomi dan pengembangan kelembagaan dan kerjasama dibagi menurut jenis kegiatan yaitu kegiatan yang bersifat rutin, insidentil, dan kontraktual.

KPHP Model Lakitan menerapkan system perencanaan bottom-up dimana kegiatankegiatannya diajukan oleh unit/bidang beserta anggarannya yang disertai dengan proposal/RAB dan disesuaikan dengan satuan biaya yang telah ditentukan. Kegiatan tersebut dituangkan dalam RKA yang akan dibahas yang dikoordinir oleh bagian teknis berkoordinasi dengan bagian keuangan. Pembahasan tersebut bertujuan untuk memastikan skala prioritas kegiatan sesuai dengan program kerja dan RPHJP KPHP. Disamping itu pembahasan tersebut juga digunakan untuk memastikan bahwa anggaran disusun secara realistis dan bertanggungjawab.

\section{Pelaksanaan (actuating)}

Pelaksanaan kegiatan dilakukan oleh unit yang mengajukan proposal. Dalam tahapan ini juga dilakukan proses monitoring dan evaluasi yang dilakukan oleh pimpinan unit masingmasing.

\section{Pengukuran (measurement)}

Sebagaimana telah tercantum dalam perencanaan, setiap kegiatan yang telah dilaksanakan harus diukur kinerjanya baik input, proses, maupun output. Proses pengukuran kinerja ini merupakan proses membandingkan rencana dan realisasi atau capaian. Adanya gap/variance harus dapat dijelaskan sehingga perbaikan kinerja dapat dilakukan secara terus menerus.

\section{Pelaporan (reporting)}

Kegiatan yang bersifat insidentil dilakukan pelaporan 1 (satu) minggu setelah kegiatan diselesaikan. Pelaksana kegiatan melakukan pelaporan kepada penanggungjawab kegiatan (pimpinan unit) dalam bentuk Laporan Pelaksanaan Kegiatan (LPK). Kegiatan yang bersifat rutin dilaporkan setiap bulan oleh pelaksana kegiatan kepada penanggungjawab kegiatan (pimpinan unit). Sementara untuk kegiatan yang dilakukan secara kontraktual dilaporkan sesuai dengan termin dan prestasi pekerjaan oleh pelaksana kegiatan. Setiap unit/bidang memberikan Laporan Perkembangan Pelaksanaan Kegiatan kepada Kepala KPHP yang kemudian dikonmpilasi di tingkat pimpinan berikut Laporan Akuntabilitas Kinerja dan dilaporkan ke Kepala Daerah serta Dewas Pengawas. Setiap laporan kegiatan di atas juga harus ditembuskan ke Satuian Pengawas Internal (SPI).

\section{Pemantauan (controlling)}

Pemantauan kegiatan secara teknis dilakukan oleh pejabat teknis, sedangkan pemantauan kegiatan secara keuangan dilakukan oleh pejabat bagian keuangan dengan melaporkan pertanggungjawaban kegiatan yang sifatnya rutin dilakukan secara periodik (bulanan, triwulanan, semesteran dan tahunan), sedangkan kegiatan kontraktual dimonitor sesuai dengan termin yang diajukan. Satuan Pengawas Internal (SPI) juga melakukan monitoring pelaksanaan kegiatan terutama dalam aspek keuangan. SPI melakukan review atau audit pada setiap unit kerja.

\section{$\underline{\text { Akuntabilitas Keuangan }}$}


Dalam hal akuntabilitas pengelolaan keuangan, KPHP Model Lakitan harus menghasilkan laporan keuangan ganda. Pertama, laporan keuangan yang akan dikonsolidasikan dengan laporan keuangan pemerintah daerah, Kedua, laporan keuangan sebagai entitas bisnis. Hal inilah yang membedakannya dari Satker biasa yang hanya membuat laporan keuangan public. Sebagai bagian dari laporan keuangan public, laporan keuangan KPHP Model Lakitan ini tetap diperiksa oleh BPK, sedangkan laporan keuangan KPHP sebagai entitas bisnis juga akan diaudit oleh auditor public sebagaimana perusahaan swasta. Hal inilah yang menjadikan PPK-BLUD memiliki kerja ekstra dalam system pelaporan keuangan, namun sekaligus untuk memastikan berjalannya akuntabilitas pengelolaan keuangan yang lebih baik.

Mekanisme manajemen dalam melaksanakan akuntabilitas keuangan adalah sebagai berikut.

\section{Perencanaan (planning)}

Perencanaan keuangan dilakukan secara bottom-up dimana setiap unit/bidang yang ada dalam kelembagaan KPHP mengajukan anggaran berdasarkan rencana yang dituangkan dalam rencana kerja untuk selanjutnya dibahas di tingkat pimpinan. Pembahasan anggaran bertujuan agar anggaran benar-benar ditujukan untuk mencapai visi dan misi KPHP. Selain itu melalui pembahasan anggaran ini dapat ditentukan prioritas anggaran sesuai dengan program kerja dan rencana strategis KPHP. Anggaran yang diajukan juga harus mencantumkan indicator kinerja baik input, proses, dan output, supaya setiap belanja/pengeluaran dapat dipertanggungjawabkan dengan baik.

\section{Pelaksanaan (actuating)}

Prosedur keuangan internal KPHP Model Lakitan PPK-BLUD diawali dengan pengajuan proposal kegiatan oleh Pelaksana Kegiatan yang dilengkapi dengan rincian anggaran kegiatan kepada pimpinan. Setelah pengajuan tersebut disetujui maka bagian keuangan dapat mencairkan anggaran.

\section{Pengukuran (measurement)}

Keberhasilan pelaksanaan pengelolaan keuangan dapat diukur dengan beberapa indicator, antara lain dengan melihat total pendapatan dan proporsi dana APBD dari total pendapatan. Selain itu indicator akuntabilitas pengelolaan keuangan dapat diukur juga dengan hasil audit yang dikeluarkan oleh auditor independen.

\section{Pelaporan (reporting)}

Secara periodic ada 3 (tiga) jenis laporan keuangan yaitu laporan triwulanan, semesteran dan tahunan. Setiap triwulanan KPHP menyusun dan menyampaikan laporan operasional dan arus kas kepada PPKD paling lambat 15 (lima belas hari) setelah periode pelaporan berakhir.Selain itu tiap semester dan tahunan KPHP wajib menyusun dan menyampaikan laporan keuangan lengkap yang terdiri dari : 
1. Laporan operasional yang berisi informasi jumlah pendapatan dan biaya KPHP selama satu periode

2. Neraca yang menggambarkan posisi keuangan yaitu asset, kewajiban dan ekuitas dana pada tanggal tertentu

3. Laporan arus kas yang menyajikan informasi kas berkaitan dengan aktivitas operasional, investasi, dan aktivitas pendanaan dan/atau pembiayaan yang menggambarkan saldo awal, penerimaan, pengeluaran dan saldo akhir kas selama periode tertentu

4. Catatan atas laporan keuangan yang berisi penjelasan naratif atau rincian dari angka yang tertera dalam laporan keuangan.

Laporan tersebut juga disertai laporan kinerja kepada PPKD untuk dikonsolidasikan ke dalam laporan keuangan pemerintah daerah paling lambat 2 (dua) bulan setelah periode pelaporan berakhir. Untuk KPHP Model Lakitan karena status kelembagaannya adalah BLUD-UPTD maka pelaporan diberikan kepada Dinas Kehutanan selaku SKPD induknya

\section{Pemantauan (controlling)}

Pemantauan pengelolaan keuangan dilakukan pada unit/bidang masing-masing melalui Surat Pertanggungjawaban (Laporan SPJ) yang dibuat. SPJ berisi laporan pertanggungjawaban keuangan yang disertai dengan bukti-bukti pengeluaran yang mendukung. Laporan ini selanjutnya dikirmkan ke bagian keuangan KPHP untuk diteliti dan dievaluasi. Bagian keuangan harus memastikan bahwa setiap belanja/pengeluaran telah didasarkan pada anggaran yang telah dibuat sebelumnya, kelengkapan dokumen pembayaran dan otorisasi pembayaran sesuai dengan mekanisme yang ditetapkan, serta kewajiban pajak dan kewajiban lainnya telah dipenuhi.

SPI akan melakukan audit internal secara periodic atas pengelolaan keuangan KPHP termasuk laporan keuangan KPHP. Audit dan evaluasi ini bertujuan untuk memastikan bahwa semua peraturan KPHP telah ditaati termasuk dalam pengelolaan keuangan agar asset yang dimiliki KPHP dapat terjaga dengan baik. Selanjutnya SPI juga akan membuat laporan hasil audit yang akan disampaikan kepada Kepala KPHP

\section{Transparansi}

Transparansi dimaksudkan untuk menjamin adanya asas keterbukaan yang dibangun berdasarkan kebebasan arus informasi agar informasi dapat diterima masyarakat yang membutuhkan secara langsung. Transparansi dalam penyelengaraan kegiatan KPHP Model Lakitan merupakan pelaksanaan tugas dan kegiatan yang bersifat terbuka bagi semua pihak baik bagi organisasi maupun masyarakat luas pengguna jasa layanan KPHP Model Lakitan Kabupaten Musi Rawas (stake holder). Prinsip transparansi meliputi proses kebijakan, perencanaan, pelaksanaan maupun pengawasan dan pengendaliannya yang 
meliputi kegiatan layanan yang diberikan oleh KPHP. Hal yang berkaitan dengan kegiatan layanan yang diberikan oleh KPHP Model Lakitan antara lain meliputi prosedur pelayanan, persyaratan teknis dan administrative pelayanan, rincian biaya pelayanan, waktu penyelesaian pelayanan, pejabat yang berwenang dan bertanggung jawab, lokasi pelayanan, standar pelayanan public, informasi pelayanan.

\section{$\underline{\text { Pengembangan Data Base untuk Peningkatan Transparansi }}$}

Data base yang lengkap dan actual sangat berguna untuk pengambilan keputusan dalam pengelolaan KPHP Model Lakitan PPK-BLUD. Selain itu data base juga bermanfaat bagi pihak luar yang membutuhkan informasi tentang KPHP seperti misalnya para peneliti atau akademisi dari pergurun tinggi, peneliti dari LSM atau NGO, instansi pemerintah terkait, dan individu masyarakat.

Oleh karena itu dalam organisasi KPHP Model Lakitan akan menyediakan petugas khusus yang bertanggungjawab untuk mengelola data base termasuk dalam pengumpulan, penyimpanan, pengolahan dan penyajian data ke dalam media informasi yang siap digunakan. Data dan informasi dapat dikumpulkan dari unit-unit pengelola di lapangan dan juga dari luar. Meskipun demikian tidak setiap data diberikan begitu saja dengan pihak luar.

Dalam proses pemberian data dan informasi kepada pihak luar harus memenuhi standar operasional prosedur (SOP) yang telah ditetapkan. Data yang dikumpulkan dapat berupa analog atau manual (peta, dokumen, laporan, data penelitian dan lain-lain), dapat juga berupa data digital (dokumen data GIS dan data digital lainnya). Unit yang mengelola data base ini secara khusus merupakan division support system atau pendukung system organisasi KPHP Model Lakitan yang diperlukan untuk pengambila keputusan dari tingkat KPH hingga unit terkecil.

\section{$\underline{\text { Audit Internal }}$}

Kegiatan ini dimulai dengan pembentukan Satuan Pengawas Internal (SPI) yang dimaksudkan untuk mendukung terciptanya system pengendalian internal yang efektif dalam organisasi KPHP baik yang menyangkut masalah teknis, asset maupun keuangan. Keberadaan SPI diharapkan dapat mendukung terwujudnya penerapan prinsip-prinsip transparansi dalam penyelenggaraan kegiatan KPHP dengan melaksanakan fungsi (a) 
membantu Kepala KPHP dalam melakukan pengawasan internal KPHP, (b) memberikan rekomendasi perbaikan untuk mencapai visi dan misi KPHP secara ekonomis, efisien dan efektif, (c) bekerjasama dengan unit/bidang terkait dalam membantu efektivitas penerapan pola tata kelola KPHP PPK-BLUD, dan (d) menangani permasalahan yang berkaitan dengan adanya indikasi korupsi yang dapat menimbulkan kerugian KPHP.

Selain itu sebagaimana yang telah diuraikan sebelumnya bahwa dalam rangka mewujudkan transparansi dalam pengelolaan keuangan KPHP, secara periodic KPHP harus menyusun laporan keuangan sesuai dengan standar akuntansi keuangan yang meliputi laporan neraca, laporan aktivitas, laporan arus kas, dan catatan atas laporan keuangan.

\section{Partisipatif}

Pengelolaan KPHP Model Lakitan yang partisipatif dapat diartikan sebagai bentuk pengelolaan yang melibatkan masyarakat di dalam dan sekitar kawasan. Skema pelibatan masyarakat ini dapat melalui skema HKm, HTR ataupun hutan desa. Belajar dari pengelolaan kawasan hutan di KPH Yogyakarta, partisipasi masyarakat dalam pengelolaan hutan memegang peranan sangat penting. Berdasarkan hasil wawancara dengan Kepala Balai KPH Yogyakarta dapat diketahui bahwa sebelum dilakukan pelibatan masyarakat sulit sekali bagi KPH ini untuk menanam apalagi membesarkan jenis jati yang disebut Jati Unggul Nusantara (JUN). Hal ini disebabkan karena masyarakat cenderung menganggap bahwa keberadaan perkebunan jati tersebut akan mengganggu kelangsungan hidup mereka, dimana selama ini lahan tersebut digunakan oleh masyarakat untuk memenuhi kebutuhan hidup mereka dengan berkebun dan berladang. Sebelum dilakukan pelibatan masyarakat seringkali dijumpai pohon jati yang mati atau tercabut dari tanah yang disinyalir dilakukan oleh masyarakat. Namun, setelah menggunakan pendekatan partisipatif dimana masyarakat diberikan kesempatan untuk mengelola kawasan hutan jati, misalnya dengan menanam rumpon di sela-sela pohon jati dan mereka juga dipekerjakan untuk mengurus pohon-pohon jati tersebut maka sejak itu tidak lagi ditemui kendala atau masalah sebelum dilakukan pelibatan masyarakat

\section{KESIMPULAN}


Dari uraian sebelumnya maka dapat ditarik beberapa kesimpulan sebagai berikut: Pertama, berdasarkan ketentuan persyaratan penerapan PPK BLUD, yang meliputi persyaratan substantif, teknis dan administratif pada prinsipnya KPHP Lakitan telah memenuhi semua persyaratan tersebut sehingga sangat memungkinkan untuk menerapkan PPK BLUD dalam pengelolaan kawasan hutan. Kedua, melalui PPK BLUD diantisipasi akan dapat memberikan keluasan wewenang pada KPHP Model Lakitan untuk melakukan pengelolaan keuangan dengan tetap mengedepankan prinsip-prinsip transparansi, akuntabilitas dan partisipatif.

Saran yang dapat peneliti berikan adalah bahwasannya KPHP Lakitan masih memerlukan dukungan baik dari pemerintah daerah maupun pemerintah pusat terutama dari segi pendanaan sampai KPHP Model Lakitan mencapai kemandirian finansial sehingga semua pihak baik pusat maupun daerah tetap harus memberikan dukungan sepenuhnya

\section{DAFTAR PUSTAKA}

Arizona, Yance, 2012. Simalakama Kawasan Hutan

Elvyda dan Sylviani, 2010. Peran dan Koordinasi Para Pihak dalam Pengelolaan KPH, Jurnal Analisis Kebijakan Kehutanan Vol.7 No.3, hal.227-246.

Kartodiharjo, Hariadi, 2011. Pembangunan Kesatuan Pengelola Hutan (KPHP): Konsep, Peraturan Perundangan dan Implementasi”, Kementerian Kehutanan, Direktorat Jenderal Planologi Kehutanan, Direktorat Wilayah Pengelolaan dan Penyiapan Areal, Pemanfaatan Kawasan Hutan, Jakarta.

Kartodihardjo, Hariadi, 2013. Kembali ke Jalan Lurus, Kritik Penggunaan Ilmu dan Praktek Kehutanan Indonesia, FORCI Development dan Tanah Air Beta, Yogyakarta.

Kusumedi P dan Rizal, A, 2010. Analisis Stakeholder dan Kebijakan Pembangunan KPH Model Maros di Porvinsi Sulawesi Selatan, Jurnal Analisis Kebijakan Kehutanan Vol.7 No.3, hal.179-193.

Lexy J Moleong, 2004. Metode Penelitian Kualitatif, Remaja Rosda Karya, Bandung.

Moh. Nazir. Ph. D, 2003. Metode Penelitian, PT. Ghalia Indonesia, Jakarta.

Nugroho, Bramasto, 2013. Pola Pengelolaan Keuangan Badan Layanan Umum Daerah Menuju Kemandirian KPH

Nugroho, Bramasto,2012. Konsep Kebijakan Sistem Pengelolaan Investasi dan Keuangan Kesatuan Pengelola Hutan (KPH)

Pandriadi, 2011. Kajian Kelayakan Badan Layanan Umum - Balai Latihan Kerja (BLUBLK) Dinas Tenaga Kerja dan Transmigrasi Kabupaten Musi Rawas, Lembaga Penelitian Universitas Sriwijaya. 
Peraturan Bupati Nomor 27 Tahun 2010 Tentang Pembentukan Unit Pelaksana Teknis Dinas Kehutanan Kabupaten Musi Rawas

Puspariani, Julijati, 2011. Implementasi Kebijakan Pembangunan Kesatuan Pengelola Hutan Produksi (KPHP) Model Lalan Kabupaten Musi Banyuasin, Universitas Diponegoro, Semarang.

Rizal, et al, 2011, Kajian Strategi Implementasi Kesatuan Pengelolaan Hutan (KPH): Studi Kasus di Kabupaten Tana Toraja Provinsi Sulawesi Selatan, Jurna Analisis Kebijakan Kehutanan, Vol.8 No.2, hal. 167-188.

Surat Keputusan Menteri Kehutanan Nomor 200 Tahun 1991 Tentang Pembentukan Kesatuan Pengusahaan Hutan Produksi.

Surat Keputusan Menteri Kehutanan Nomor 790 Tahun 2009 Tentang Pembentukan KPHP Rawas dan KPHP Model Lakitan.

Sutton, Rebecca,1999. The Policy Process:An Overview, Overseas Development Institute.

Undang-Undang Nomor 5 Tahun 1967 tentang Pokok Kehutanan

Undang-Undang 41 Tahun 1999 Tentang Pembaruan Undang-Undang Pokok Kehutanan (UU No 5 Tahun 1967).

Undang-Undang Nomor 17 Tahun 2003 Tentang Keuangan Negara.

Undang-Undang Nomor 1 Tahun 2004 Tentang Perbendaharaan Negara.

Zakaria, Yando, 2013. Masa Depan Dinamika Perebutan SDA Pasca Keputusan MK Tentang Hutan Adat dalam Perspektif Kebijakan Tentang Masyarakat Hukum Adat/Masyarakat Adat; Studi Kasus Kutai Barat 